\title{
Adsorption of Methyl Orange from Wastewater by using Biochar
}

\author{
Mohammed Abdulrahman Hanoon and Muthanna J. Ahmed
}

Chemical Engineering Department, College of Engineering, University of Baghdad

\begin{abstract}
The biochar prepared from sawdust raw material was applied in this study for the treatment of wastewater polluted with methyl orange dye. The effect of $\mathrm{pH}(2-11)$, initial concertation $(50-250 \mathrm{mg} / \mathrm{L})$ and time were studied. The isotherm of Langmuir, Frendluch and temkin models studied. The Langmuir model was the best to explain the adsorption process, maximum uptake was $136.67 \mathrm{mg} / \mathrm{g}$ at $25 \mathrm{C}^{\circ}$ of methyl orange dye. Equilibrium reached after four hours of contact for most adsorbents. The values of thermodynamic parameters $\Delta \mathrm{G}$ were negative at various temperatures, so the process spontaneous, while $\Delta \mathrm{H}$ values were $16683 \mathrm{j} / \mathrm{mol}$ and $\Delta \mathrm{S}$ values was $60.82 \mathrm{j} / \mathrm{mol} . \mathrm{k}$.
\end{abstract}

Keywords: anionic dye, adsorption, biochar, endothermic

Received on 21/01/2019, Accepted on 26/02/2019, published on 30/09/2019

https://doi.org/10.31699/IJCPE.2019.3.4

\section{1- Introduction}

Water is the most important source for human life, where the human use it for drinking, washing, agriculture and other uses to support his life. Water can be contaminated when the quality or composition of water is different due to the activity of humans.

Increasing industrial activities increase environmental pollution problems [1].

There are a lot of substances that can pollution water such as inorganic acids, salts, alkali, organic matter, and dyes. Wastewaters contaminated with dye represent the most amounts of the discharged industrial water.

Water polluted happened due to the use of large quantities of water in manufacturing processes and the first clear sign of water-polluting is color because of dyes [2].

Dyes are widely used by a human from antiquity and it was extracted from plants such as indigo and animals such as carmine, cochineal.

Humans depended on the natural sources of dyes until 1856, after that, William Henry Perkin trying to synthesize artificial quinine, in order to treat malaria and using allyltoluidine, has succeeded in produce aniline: a basic dye. This was the discovery of the first material synthetic dye [3].

Dyes are synthetic organic compounds with complex molecular structures and high molecular weights. These properties increase the difficulties of the treatment of dye wastewater.

In general, the main modes of classification of dyes are based either on their chemical constitution or on their methods of application to different substrates such as textile fibers, paper, leather, plastics, etc.
The different dye classes of these dyes are defined by their auxochromes, and are essentially, which is mordant dyes, direct dyes, disperse dyes, insoluble or developed azo dyes, vat dyes, reactive dyes, acidic or anionic dyes, and basic or cationic dyes. This classification allows dyers, to know the suitable dye required. It's clear that information like solubility in the dye bath, the affinity for the chosen fiber and the nature of the fixation are required for this kind of industry [4].

Dyes are widely used in sweets, fruit paste, green liquor, pastry both for cakes and pies as for biscuits syrup and lemonade; the cheese dairy, butter and margarine (yellow coloring) [5]. Releases of textile effluents, carrying dyes, into rivers, can greatly harm animals, plants, and micro-organisms living in these waters. This toxicity, therefore, could be related to the decrease of dissolved oxygen in these media. Moreover, their very low biodegradability, due to their high molecular weight and their complex structures, give them a character toxic that can be high or low.

As a result, they can persist for a long time in this medium, thus generating significant disturbances in the different mechanisms existing natural resources in the flora (decrease in the self-purification power of rivers, inhibition of the growth of aquatic plants and in wildlife (decimation of certain categories of fish, microorganisms) [6]. The dangers of textile waste are partly short-term (obvious dangers) and secondly, in the long run.

Depollution techniques most commonly fall into three categories: physical processes involving precipitation methods (coagulation, flocculation, sedimentation), reverse osmosis-filtration, adsorption (on biochar ,activated carbon, zeolite....etc) and then incineration; chemical processes, with oxidation (oxygen, ozone,

Corresponding Authors: Name: Mohammed Abdulrahman Hanoon, Email: mmdalsaeedy90@yahoo.com, Name: Muthanna J. Ahmed, Email: muthannaj@yahoo.com 
oxidants such as $\mathrm{NaOCl}, \mathrm{H} 2 \mathrm{O} 2$ ), the complex metric methods, the use of the resin ion exchange and then the reduction (using for example $\mathrm{Na} 2 \mathrm{~S} 2 \mathrm{O}$ ); biological processes, using aerobic treatment (with oxygen) or anaerobic treatment (without oxygen) [7].

Among the above mention of methods, adsorption is a process of transferring the pollutant from its source environment or fluid phase (liquid or gaseous) to the surface of the adsorbent (solid). This mode of treatment remains very limited to the elimination of different dyes. Only, the cationic dyes, mordant dyes, dispersed, reactive and vat are eliminated by this technique[8].

Adsorption occurs mainly in four stages. Below are the different areas in which the molecules can be found organic or inorganic adsorption processes: diffusion of the adsorbate, from the external liquid phase, to that located in the vicinity of the surface of the adsorbent; extragranular diffusion of the material (transfer of the solute through the liquid film to the grain surface; intra-granular transfer of matter (transfer of matter into the structure porous outer surface of seeds to active sites; and adsorption reaction in contact with active sites. Once adsorbed, the molecule is considered immobiled [9], [10].

In the last years, biochar has become very important in agriculture in terms of improving the quality of soil and productivity of agricultural crops as well as in food preservation. Biochar is a granular and porous material, which is usually produced by the pyrolysis process of the raw materials at conditions that have no oxygen.

The surface area and the porosity of biochar are usually high, so it is used as an absorbent to adsorb the contaminants from aqueous solutions as in the activated carbon. In this study, biochar was prepared from low cost and locally available raw material represented by sawdust.

The characters surface area and total pore volume of the biochar were $58.845 \mathrm{~m} 2 / \mathrm{g}$ and $0.061 \mathrm{~cm} 3 / \mathrm{g}$. Therefore, the biochar has great importance in addressing and controlling the environmental pollutants [11].

\section{2- Experimental Work}

\subsection{Preparation of adsorbate}

Anionic dye used was Methyl orange (Sodium4-\{[4 (dimethylamino) phenyl]diazenyl \}benzene-1-sulfonate) purity of $99.9 \%$ with molecular weight of $327.33 \mathrm{~g} / \mathrm{mol}$, was used as adsorbate. The chemical formula of Methyl orange was $\mathrm{C} 14 \mathrm{H} 14 \mathrm{~N} 3 \mathrm{NaO} 3 \mathrm{~S}$. The solutions concentration were prepared by adding a known weight of dyes to $100 \mathrm{ml}$ distilled water. The methyl orang in the aqueous solution was analyzed using UV-Visible Spectrophotometer. The wavelength corresponding to maximum absorbance was $466 \mathrm{~nm}$.

\subsection{Batch Experiments}

The Methyl orange uptake experiments were conducted as follows: weighting $0.02 \mathrm{~g}$ of biochar with particle size about $200 \mu \mathrm{m}$ and then added to the flask containing 40 $\mathrm{ml}$ of dye solution. The flasks were put in a shaker at speed $150 \mathrm{rpm}$ at room temperature.

After that, samples were filtered and the concentration of dye was calculated using UV-Visible Spectrophotometer. The adsorption variables study was: time (15-360 min), initial concertation (50-250 ppm) and $\mathrm{pH}$ (2-11). Also, the adsorption isotherm models Freundlich, Langmuir and Temkin, were used to fit data of experimental equilibrium isotherm data. The adsorption isotherms for the aqueous solution with various initial concentrations are 50,100, 150, 200, and $250 \mathrm{ppm}$ for 24 hours. Thermodynamic parameters were studied at different temperatures $\left(25-45 \mathrm{C}^{\mathrm{o}}\right)$. The dye adsorption at equilibrium, $\mathrm{q}_{\mathrm{e}}(\mathrm{mg} / \mathrm{g})$, was calculated as following shown in Eq. (1) [12]:

$\mathrm{qe}=\frac{\left(C_{0}-C e\right) \mathrm{v}}{W}$

Where: $\mathrm{C}_{\mathrm{o}}(\mathrm{mg} / \mathrm{l})$ is the primary concentration of dyes. $\mathrm{C}_{\mathrm{e}}(\mathrm{mg} / \mathrm{l})$ is the equilibrium concentration of dyes. $\mathrm{V}$ (l)is the dye solution volume.

$\mathrm{W}(\mathrm{g})$ is the weight of biochar.

\section{3- Results and Discussion}

\subsection{FT-IR Analysis}

The biochar was studied by infrared spectroscopy FTIR to determine the different chemical functions present on the surface of biochar before and after the adsorption process. It is a complementary technique that focuses in general on the study of samples at a molecular level.

Fig. 1 shows the FTIR spectra of biochar before and after adsorption of methyl orange. Generally, the bands are due to different surface groups. A broad absorption band around $3,423 \mathrm{~cm}-1$ is attributed to the $\mathrm{O}-\mathrm{H}$ stretching vibration of hydroxyl functional including hydrogen bonding due to adsorbed water. The disappearance of the hydroxyl group is due to the adsorption of the methyl orange on the surface of the biochar. The decrease of the intensity came from the extra layer of methyl orange which increases the absorption of the infrared spectrum, leading to a decrease in the transmission intensity.

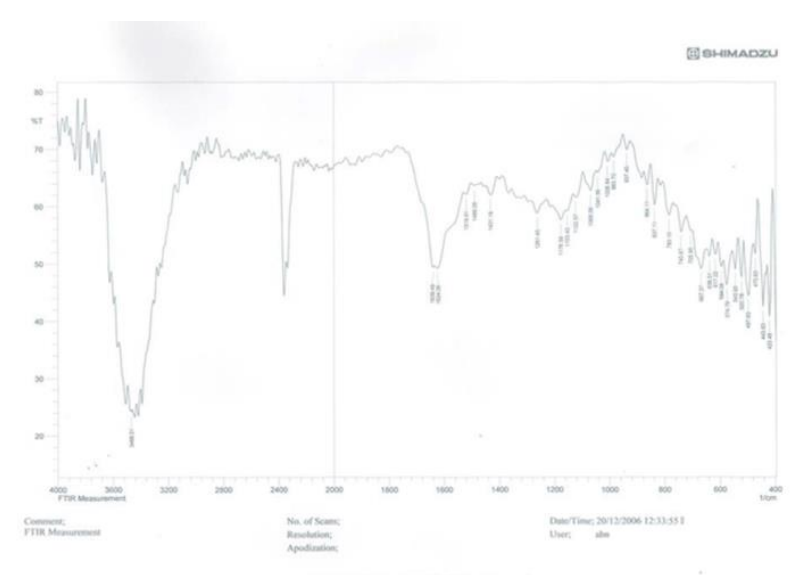

(a) 


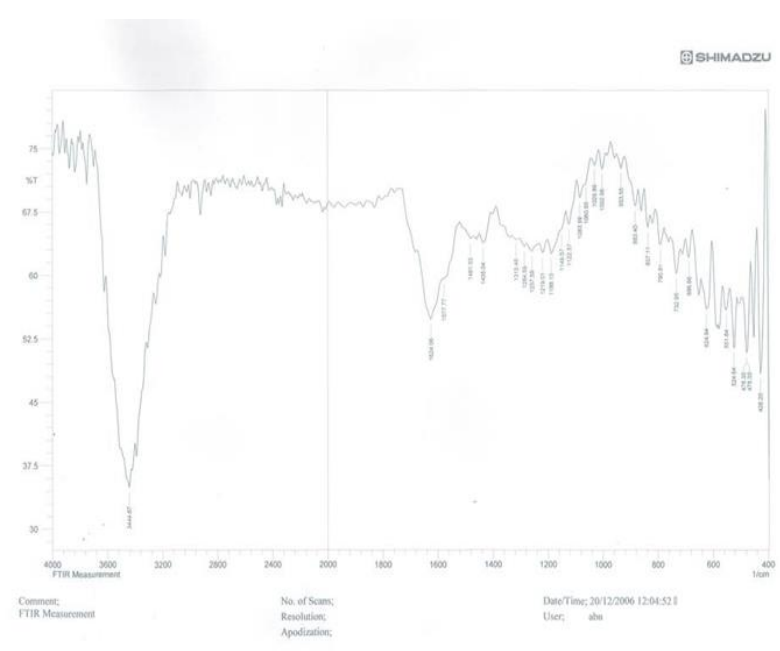

(b)

Fig. 1. FTIR peaks of biochar, (A) before adsorption, (B) after adsorption

\subsection{PH Effect}

The aqueous solution $\mathrm{pH}$ parameter is an important factor affects the dye adsorption capacity. Therefore, methyl orange dye adsorption on the biochar was tested in the $\mathrm{pH}$ value range (2-11). The results of the initial $\mathrm{pH}$ effect on the dye uptake are shown in Fig. 2 Figure 2 shows that the adsorption is favored by decreasing the initial $\mathrm{pH}$. For initial $\mathrm{pH}$ values ranging from 3 to 5, sorption is accompanied increase by the initial $\mathrm{pH}$ decrease. On the other hand, when the initial $\mathrm{pH}$ varies from 6 to 11, the sorption is accompanied decrease by an increase in initial $\mathrm{pH}$. This may be referring to the competition from available excess $\mathrm{OH}$-ions with the dye anionic molecule for the active sites. While, acidic conditions are favorable for the adsorption between the dye and adsorbent because in case exist high electrostatic, attraction between the anionic dye and the surface charger positively of the adsorbent under acidic conditions [13].



Fig. 2. pH effect on the adsorption of $\mathrm{MO}(\mathrm{W}=0.02 \mathrm{~g} / 40$ $\mathrm{ml}$, initial concentration $=100 \mathrm{mg} / 1, \mathrm{~T}=25^{\circ} \mathrm{C}$, speed $=150$ $\mathrm{rpm}$, time $=240 \mathrm{~min}$, biochar particle size $=200 \mu \mathrm{m}$ )

\subsection{Initial Concentration Effect}

The capacity of adsorption for the biochar at various initial methyl orange concentrations is shown in Fig. 3

When the initial dye concentrations increased up to 250 $\mathrm{mg} / \mathrm{L}$, it is observed that the amounts of uptake increased. This may be due to the concentration that provides an important driving force to overcome all mass transfer resistance of the dye between the aqueous and solid phase.

Hence a higher initial concentration of dye will enhance the adsorption process, this agrees with [12], [13],[14].

The amounts of adsorption of MO increased from 48 to $121 \mathrm{mg} / \mathrm{g}$, when the initial dyes concentration increased from 50 to $250 \mathrm{mg} / \mathrm{L}$.

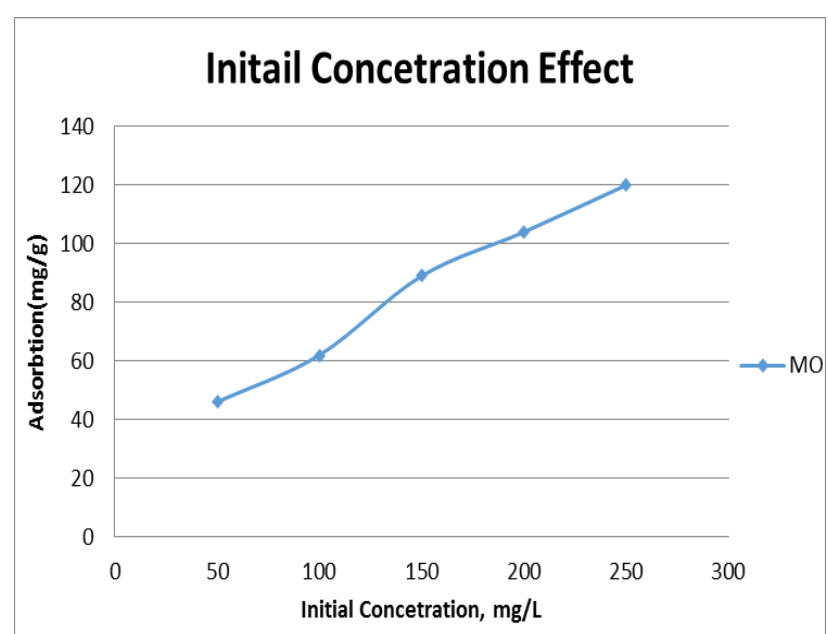

Fig. 3. Effect of initial concentration on the uptake of $\mathrm{MO}$ $\left(\mathrm{W}=0.02 \mathrm{~g} / 40 \mathrm{ml}, \mathrm{T}=25^{\circ} \mathrm{C}\right.$, speed $=150 \mathrm{rpm}$, time $=240$ min, biochar particle size $=200 \mu \mathrm{m}$ )

\subsection{Contact Time Effect}

The contact time effect was studied at time range of $(0.15-6 \mathrm{~h})$ at an initial dye concentration of $100 \mathrm{mg} / \mathrm{L}$ is explained in Fig. 4.

The amount of adsorbed increased rapidly in initial stage up to $2 \mathrm{hrs}$, and then gradually decreased with further process of the adsorption.

Finally, equilibrium achieved after $4 \mathrm{hrs}$ and adsorption uptake for MO was $75 \mathrm{mg} / \mathrm{g}$. The rapid adsorption in initial stage can be attributed to higher availability of active sites on adsorbent surface.

With the passage of time, these active sites are gradually occupied by dye molecules which lead to decrease in number of active sites available for the residual dye molecules in solution. Similar behavior has been reported in previous literature [13], [15]. 


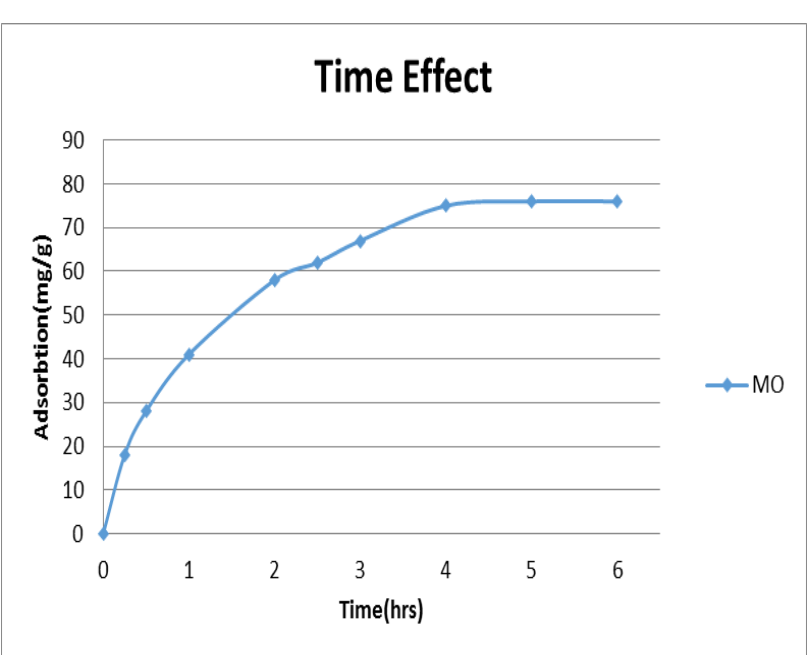

Fig. 4. Effect of agitation time on the uptake of $\mathrm{MO}$ $(\mathrm{W}=0.02 \mathrm{~g} / 40 \mathrm{ml}$, initial concentration $=100 \mathrm{mg} / \mathrm{l}, \mathrm{T}=$ $25^{\circ} \mathrm{C}$, speed $=150 \mathrm{rpm}$, biochar particle size $=200 \mu \mathrm{m}$ )

\subsection{The Thermodynamic Parameters}

The change of Gibbs free energy $(\Delta \mathrm{G})$, enthalpy $(\Delta \mathrm{H})$ and entropy $(\Delta S)$ are the characteristics of thermodynamics of the adsorption system.

The value of Gibbs's free energy, enthalpy, and entropy obtained from the intercept and slope of drawing data of LnKc versus $1 / \mathrm{T}$ as shown in Fig. 5 where thermodynamic parameters calculated from Eq. (2) and Eq. (3).and the Kc calculated from Eq. (4) [16].

The thermodynamic parameters tabled in Table 1. The positive values of enthalpy for Methyl Orange indicate that the adsorption is endothermic and this value is less than $20 \mathrm{KJ} / \mathrm{mol}$ which refers to phsicosorption process, while the value of entropy is positive reflects the affinity of MO for the biochar where the degree of disorder increases.

The value of free energy of the thermodynamic process $(\Delta G)$ at the different temperatures was negative and rise with heating, which mean spontaneous and favorable adsorption at high temperature.

$\ln K_{C}=\left(\frac{\Delta S^{\circ}}{R}\right)-\left(\frac{\Delta H^{\circ}}{R T}\right)$

$\Delta \mathrm{G}^{\circ}=-R T \ln K_{c}$

$\mathrm{K}_{\mathrm{C}}=\frac{\mathrm{Cad}}{\mathrm{Ce}}$

Where: Kc: is the equilibrium constant, $\mathrm{C}_{\mathrm{ad}}$ is the concentration of $\mathrm{MO}$ adsorbed on the adsorbent per liter of the solution $\left(\mathrm{mg} . \mathrm{l}^{-1}\right)$, Ce: is equilibrium concentration of $\mathrm{MO}$ in the solution (mg. $\left.\mathrm{l}^{-1}\right), \mathrm{R}$ : is the universal constant gas $(8.314 \mathrm{~J} / \mathrm{mole} . \mathrm{K}), \mathrm{T}$ : is the solution temperature $(\mathrm{K})$

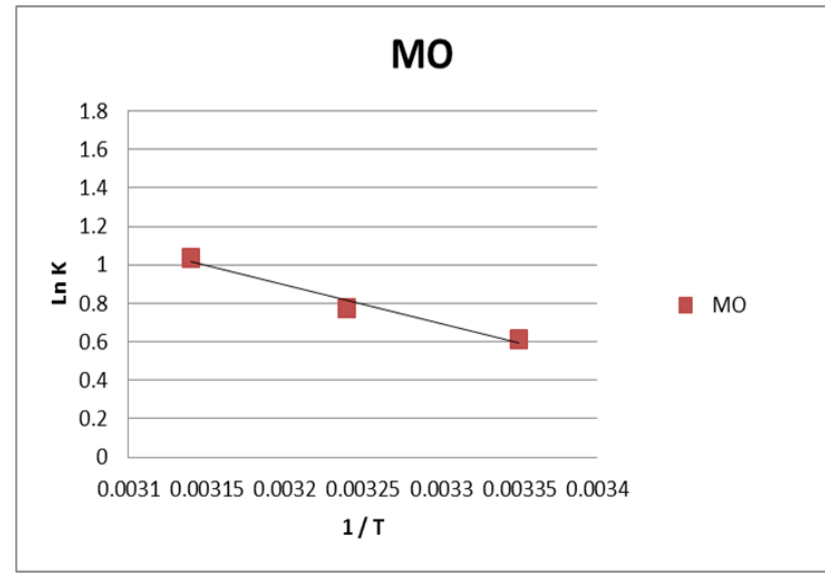

Fig. 5. Thermodynamic adsorption of MO on biochar.

Table 1. The thermodynamic parameters for the sorption of $\mathrm{MO}$ on biochar

\begin{tabular}{lcccc}
\hline Adsorbent & $\mathrm{T}, K$ & $\Delta \mathrm{G}, \mathrm{Kj} / \mathrm{mol}$ & $\Delta \mathrm{H}, \mathrm{Kj} / \mathrm{mol}$ & $\begin{array}{c}\Delta \mathrm{S}, \\
j / m o l . k\end{array}$ \\
\hline & 298 & -1440.67 & & \\
Methyl Orange & 308 & -2048.86 & 16683.7 & 60.82 \\
& 318 & -2657.1 & & \\
\hline
\end{tabular}

\section{4- Adsorption Isotherm Models}

The adsorptive capacity of dye by biochar was studied using the initial concentration of dyes. The experimental conditions are identical to those used previously.

The results obtained were fitted to by three empirical models: Langmuir, Freundlich and temkin. These three models are a widely used tool for the adsorption mechanism and the quantification of the adsorbent / adsorbate affinity.

These linear models are plotted in Fig. 6, listed in Table $\mathbf{2}$ and the results are shown in Table $\mathbf{3}$.

It is observed that the adsorption of methyl orange by bio char is satisfactorily described by the Langmuir model with $\mathrm{R}^{2}(0.9958)$ which is higher than the value that given by the Freundlich model with $\mathrm{R}^{2}(0.9778)$ and Temkin with $\mathrm{R}^{2}(0.9578)$.

This means monolayer coverage of methyl orange molecules on biochar surface. The max absorption capacity for MO on bio char was $136.67 \mathrm{mg} / \mathrm{g}$.

The maximum adsorption uptake for Langmuir model for methyl orange is compared with the other different source of adsorbates as shown in Table 4. 


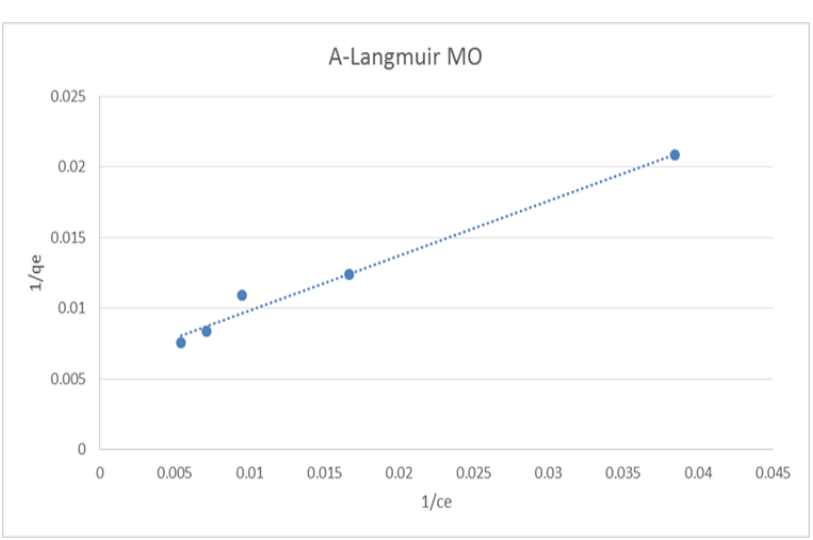

(a)

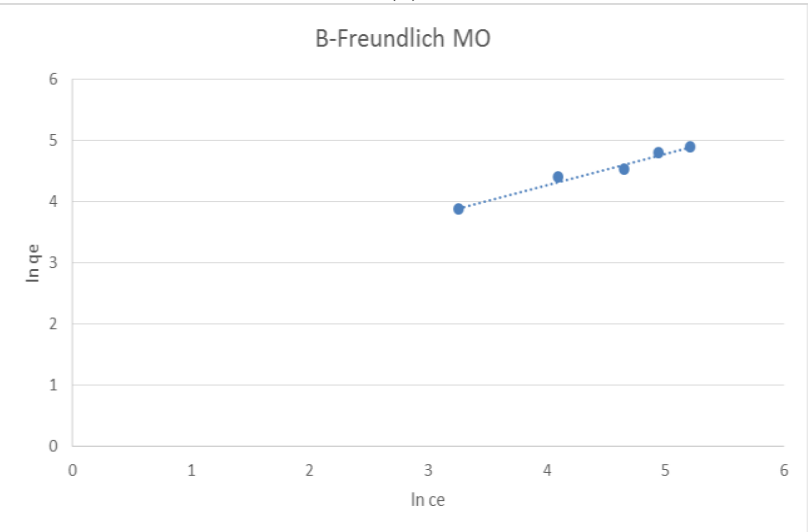

(b)

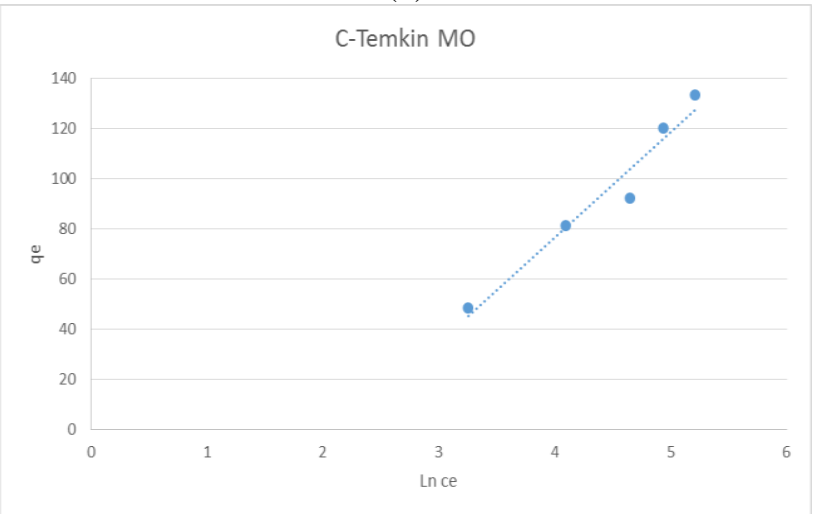

(c)

Fig. 6. Isotherm of $\mathrm{MO}$ on biochar (A) Langmuir (B) Freundlich(C)Temkin

Table 2. Equations for the adsorption isotherm models

\begin{tabular}{lll} 
Model & Equation used & Reference \\
\hline Langmuir Isotherm & $\frac{1}{q_{e}}=\frac{1}{q_{m} k l C_{e}}+\frac{1}{q_{m}}$ & {$[17]$} \\
Freundlich Isotherm & $\log \mathrm{q}_{\mathrm{e}}=\log \mathrm{K}_{\mathrm{f}}+\frac{1}{n} \log \mathrm{C}_{\mathrm{e}}$ & {$[17]$} \\
Temkin isotherm & $\mathrm{q}_{\mathrm{e}}=\mathrm{B} \ln \mathrm{A}+\mathrm{B} \ln \mathrm{C}_{\mathrm{e}}$ & [17]
\end{tabular}

Table 3. Parameters of isotherms model for adsorption of MO

\begin{tabular}{lll}
\hline Type of isotherm & parameters & Methyl Orange \\
\hline \multirow{3}{*}{ Langmuir } & $\mathrm{q}_{\mathrm{m}}$ & 136.67 \\
& $\mathrm{~K}_{\mathrm{L}}$ & 0.021 \\
& $\mathrm{R}^{2}$ & 0.9958 \\
Freundlich & $\mathrm{k}_{\mathrm{f}}$ & 9.297 \\
& $\mathrm{n}$ & 1.958 \\
& $\mathrm{R}^{2}$ & 0.9778 \\
Temkin & $\mathrm{A}$ & 0.112 \\
& $\mathrm{~B}$ & 42.202 \\
& $\mathrm{R}^{2}$ & 0.9578 \\
\hline
\end{tabular}

Table 4. The maximum adsorption capacities of MO Comparison with various adsorbents

\begin{tabular}{|c|c|c|}
\hline Adsorbent & $\begin{array}{l}\text { Capacity of } \\
\text { Adsorption }(\mathrm{mg} / \mathrm{g})\end{array}$ & References \\
\hline $\begin{array}{l}\text { Acid modified carbon } \\
\text { coated monolith }\end{array}$ & 147.06 & {$[18]$} \\
\hline Activated carbon & 238.1 & [19] \\
\hline Chitosan & 34.83 & {$[20]$} \\
\hline Biochar & 136.67 & The current study \\
\hline Modified Chitosan & 89.30 & {$[21]$} \\
\hline
\end{tabular}

\section{5- Conclusions}

The results obtained show that the biochar could be applied as a good adsorbent for methyl orange dye removal from an aqueous solution. It is observed that the adsorption of methyl orange by biochar is described by the Langmuir model with R2 (0.9958) which is higher than the value that given by the Freundlich model and Temkin .pH is the most important variable for adsorption anionic dyes on biochar. Methyl orange uptake was 138.2 $\mathrm{mg} / \mathrm{g}$ at initial concertation $100 \mathrm{ppm}$. The thermodynamic parameters $\left(\Delta \mathrm{G}^{\circ}, \Delta \mathrm{H}^{\circ}\right.$, and $\left.\Delta \mathrm{S}^{\circ}\right)$ at temperature range of $298-318 \mathrm{k}$ explained that the process of adsorption is endothermic. The sorption process was phsicosorption process, spontaneous and favorable adsorption at high temperature.

\section{Nomenclature}
A: $\quad$ Temkin constant $(\mathrm{L} / \mathrm{g})$.
B: $\quad$ Heat of adsorption $(\mathrm{J} / \mathrm{mol})$.
$\mathrm{C}_{\mathrm{ad}}$ : Adsorbed concentration, $\mathrm{mg} / \mathrm{L}$
$\mathrm{C}_{\mathrm{e}}$ : $\quad$ Concentration at equilibrium, $\mathrm{mg} / \mathrm{L}$
$\mathrm{C}_{\mathrm{i}}$ : Initial concentration, $\mathrm{mg} / \mathrm{L}$
$\Delta \mathrm{G}^{\circ}: \quad$ Gibbs free energy, $\mathrm{KJ} /$ mole
$\Delta \mathrm{H}^{\circ}: \quad$ Enthalpy change, $\mathrm{KJ} /$ mole
$\mathrm{K}_{\mathrm{C}}$ : Equilibrium constant
$\mathrm{K}_{\mathrm{f}}$ : $\quad$ Freundlich's constant., $\mathrm{mg} / \mathrm{g}$
$\mathrm{K}_{\mathrm{L}}$ : $\quad$ Langmuir Adsorption constant coefficient
M: $\quad$ Mass of adsorbent, $\mathrm{g}$
1/n: Constant indicative of the intensity of the adsorption 
$\mathrm{q}_{\mathrm{e}}$ : $\quad$ Sorbed dyes molecules on the adsorbent, $\mathrm{mg} / \mathrm{g}$

$\mathrm{q}_{\mathrm{m}}$ : The maximum sorption capacity for monolayer coverage, $\mathrm{mg} / \mathrm{g}$

$\mathrm{R}: \quad$ Universal gas constant

$\Delta \mathrm{S}^{\circ}: \quad$ Entropy change, $\mathrm{J} / \mathrm{K}$. mole

T: $\quad$ Temperature, $\mathrm{K}$

V: $\quad$ Volume, L

\section{References}

[1] Montazer-Rahmati, M.M., Rabbani, P., Abdolali, A. and Keshtkar, A.R., 2011. Kinetics and equilibrium studies on biosorption of cadmium, lead, and nickel ions from aqueous solutions by intact and chemically modified brown algae. Journal of hazardous materials, 185(1), pp.401-407.

[2] Chong, M.N., Jin, B., Chow, C.W.K., Saint, C., 2010. Recent developments in photocatalytic water treatment technology. A review, Water Research, , 44 (10), pp. 2997-3027.

[3] Belaid, K.D., Kacha, S., Kameche, M. and Derriche, Z., 2013. Adsorption kinetics of some textile dyes onto granular activated carbon. Journal of Environmental Chemical Engineering, 1(3), pp.496$\underline{503 .}$

[4] Eren, Z., Acar, F.N., 2006. Adsorption of Reactive Black 5 from an aqueous solution: equilibrium and kinetic studies, Desalination, 194 (1-3), 1-10.

[5] T. Robinson, B. Chandran and P. Nigam., 2002. Removal of dyes from a synthetic textile dye effluent by biosorption on apple pomace and wheat straw. Bioresource Technology 85., pp,43-49.

[6] Gupta, V.K., 2009. Application of low-cost adsorbents for dye removal-A review. Journal of environmental management, 90(8), pp.2313-2342.

[7] P. Janos, H. Buchtova and M. Ryznarova.,2003. Sorption of dyes from aqueous solutions onto fly ash. Water Res., 37., pp, 4938-4944.

[8] Gautam, R.K., Mudhoo, A. and Chattopadhyaya, M.C., 2013. Kinetic, equilibrium, thermodynamic studies and spectroscopic analysis of Alizarin Red S removal by mustard husk. Journal of Environmental Chemical Engineering, 1(4), pp.1283-1291.

[9] Hameed, B.H., Din, A.M. and Ahmad, A.L., 2007. Adsorption of methylene blue onto bamboo-based activated carbon: kinetics and equilibrium studies. Journal of hazardous materials, 141(3), pp.819-825.

[10] Chen, H., Zhao, J., Dai, G., 2011. Silkworm exuviae. A new non-conventional and low-cost adsorbent for removal of methylene blue from aqueous solutions. Journal of Hazardous Materials 186, 1320-1327.

[11] Bouras,H.D.,Yeddou,A.R.,Bouras,N.,Hellel,D., 2017. Biosorption of Congo red dye by Aspergillus carbonarius $\mathrm{M}_{333}$ and Penicillium glabrum Pg1: Kinetics, equilibrium and thermodynamic studies. Journal of the Taiwan Institute of Chemical Engineers 80,915-923.
[12] Varlikli, C., Bekiarib, V., Kus, M., Boduroglu, N., Oner, I., Lianos, P., Lyberatos, G.,Icli, S. (2009). Adsorption of dyes on Sahara desert sand. Journal of Hazardous Materials 170, 27-34.

[13] Taha, Dakhil \& Samaka, Israa. (2012). Natural Iraqi palygorskite clay as low cost adsorbent for the treatment of dye containing industrial wastewater. \begin{tabular}{lllll}
\hline Journal of oleo science. $61.729-36$.
\end{tabular} 10.5650/jos.61.729.

[14] Raghad F.Almilly.,Mohanned H.Hasan,2017 'Waste Water Treatment by Liquid-Solid Adsorption Using Calcined Sand-Clay Mixture Adsorbent' Iraqi Journal of chemical and petroleum Engineering.vol.18.No.2.67-81.

[15] Jenan A.Al-Najar.,2017'Removal of dyes from synthetic wastewater by agricultural waste' Iraqi Journal of chemical and petroleum Engineering.vol.18.No.3.31-48

[16] Basma A. AbdelMajeed., Raheem J.Muhseen., Nawras J.Jassim.,2018'Adsorption of Diclofenac Sodium and Ibuprofen by Bentonite Polyureaformaldehyde Thermodynamics and Kinetics Study' Iraqi Journal of chemical and petroleum Engineering.vol.19.No.1.29-43. 


\section{امتزاز صبغه المثيل البرثقالي من المحلول المائي باستخدام الفحم الحيوي \\ محمد عبد الرحمن حنون و مثنى جبار احمد \\ قسم الهنسة الكيمياوية ، كلية الهندسة ، جامعة بغداد}

الخلاصة

تم استخدام الفحم النباتي المحضر من نشارة الخشب في هذه الدراسة لمعالجة المياه الملوثة بصبغة المثيل البرتقالي. تمت دراسة تأثير الأس الهيدروجيني (2-11) وتأثثر التركيز الأولي (50-250 ملغم / لتر) والوقت. كما تم دراسة موديلات الايزوثيرم لانكماير وفرندليش وتيمكن. لوحظ ان افضل موديل ينطبق لشرح عملية الامتزاز هو لانكماير • وكان الحد الأقصى للامتصاص 136.67 ملغم / جم عند 25 درجة مئوية لصبغة المثيل البرتقالي. تم الوصول إلى التوازن بعد أربع ساعات من اجراء عملية الامتزاز ـ كانت قيم الديناميكا الحرارية G سالبة في درجات حرارة مختلفة ، لذلك كانت العملية تلقائية ، في حين كانت قيم 16683 j / . 60.82 j / mol.k $\Delta S$ وكانت قيم mol الكلمات الدالة: الامتزاز ، الاسترجاع ، الاصباغ ، ماص للحرارة 